\title{
Effects of supplementing glycerol and soybean oil in drinking water on feed and water intake, energy balance, and production performance of periparturient dairy cows
}

\author{
V. R. Osborne, ${ }^{1}$ N. E. Odongo, ${ }^{2}$ J. P. Cant, K. C. Swanson, and B. W. McBride \\ Department of Animal and Poultry Science, University of Guelph, Ontario, Canada N1G 2W1
}

\begin{abstract}
The objective of this study was to determine the effects of supplementing glycerol and soybean oil in drinking water on feed and water intake, calculated energy balance, and production performance of periparturient dairy cows. Ninety multiparous Holstein dairy cows were randomly assigned to 1 of 3 treatments: 1 ) no nutrients supplemented in the drinking water (control); 2) $20 \mathrm{~g} / \mathrm{L}$ of glycerin supplemented in the drinking water (glycerol); and 3) $10 \mathrm{~g} / \mathrm{L}$ of soybean oil supplemented in the drinking water (SBO). The trial lasted from 7 $\mathrm{d}$ prepartum to $7 \mathrm{~d}$ postpartum. Cows were offered a close-up and milking cow TMR for ad libitum intake, pre- and postpartum, respectively. The dry matter intake of cows supplemented with glycerol and SBO was lower than for the control cows throughout the experimental period but not different from each other. Water intake for the control cows was greater than the average for the glycerol and SBO cows prepartum, and greater than for SBO cows but similar to that of glycerol cows postpartum. Glycerol cows consumed more water than SBO cows. There were no differences in energy intake and energy balance of the cows pre- and postpartum. Serum triacylglycerol concentration for glycerol cows was lower than for the control and SBO cows prepartum and was lower than for the SBO cows postpartum. There were no differences in the serum nonesterified fatty acids and glucose concentrations throughout the experiment. There were no differences in the serum $\beta$-hydroxybutyrate (BHBA) concentrations at parturition, but serum BHBA concentration of the glycerol cows was greater than for control and SBO cows during the prepartum period. However, during the postpartum period, serum BHBA concentrations of the
\end{abstract}

Received July 14, 2008.

Accepted September 7, 2008.

${ }^{1}$ Corresponding author: vosborne@uoguelph.ca

${ }^{2}$ Current address: Animal Production and Health Section, Joint FAO/IAEA Division of Nuclear Techniques in Food and Agriculture, Department of Nuclear Sciences and Applications, International Atomic Energy Agency, PO Box 100, Wagramer Strasse 5, A-1400 Vienna, Austria. control cows were greater than for glycerol and SBO cows. There were no differences in calf birth weights or milk yield and composition. Although the glucogenic property of glycerol supplemented in the drinking water at $20 \mathrm{~g} / \mathrm{L}$ may not have been sufficient to elicit a milk yield response, it did reduce the concentration of BHBA postpartum.

Key words: glycerol, soybean oil, drinking water, transition period

\section{INTRODUCTION}

The transition period can be divided into 2 phases: 7 to $0 \mathrm{~d}$ prepartum, characterized by a $30 \%$ reduction in DMI (Grummer, 1995), and 0 to $21 \mathrm{~d}$ postpartum, when intake increases rapidly. The transition period remains a problematic area on many dairy farms, and metabolic disorders continue to occur at economically important rates on commercial dairy farms (Burhans et al., 2003). Furthermore, many of the metabolic disorders afflicting dairy cows during the periparturient period are interrelated and are linked to the diet fed during the prepartum period (Curtis et al., 1985). Several excellent reviews have been written to describe the metabolic adaptations in energy, protein, and mineral metabolism required for dairy cows to transition successfully to lactation (e.g., Grummer, 1993; Drackley et al., 2001; Overton and Waldron, 2004) and the rapid increase in energy demand at parturition has resulted in recommendations for energy dense diets 2 to $3 \mathrm{wk}$ before and after parturition (NRC, 2001).

Water is an important nutrient in dairy production (Houpt, 1984; Murphy, 1992). Osborne et al. (2002) showed that glucose supplementation in the drinking water of transition cows improved the $\mathrm{N}$ status of the cow by reducing rumen ammonia levels and blood urea. Thomas et al. (2007) showed that flavoring agents need not be added only to the starter feed for calves, but that flavor can also stimulate DMI and BW gain when added in drinking water. Additionally, Osborne et al. (2008), in an attempt to bypass the rumen with fish oil and increase n-3 polyunsaturated fatty acids in milk, showed that drinking water was a useful vehicle to ad- 
minister nutrients to dairy cows. Furthermore, because dietary fat largely bypasses the portal venous system and is released into circulation via thoracic lymph nodes, the fat can be used for energy by nonhepatic tissues, thus sparing glucose. However, there is no information on the effects of fat supplementation in the drinking water of transition dairy cows on the energy content of colostrum, energy balance of the cows, or the birth weight of the calves. Additionally, the increased production of glycerin (or glycerol) from the biodiesel industry has made various forms of glycerin readily available and an attractive glucogenic substrate for feeding livestock. This is especially important with the reduced availability and higher price of corn because of demand by the ethanol industry. The objective of this study was to determine the effects of supplementing glycerol and soybean oil in drinking water on feed and water intake, energy balance, and production performance of periparturient Holstein dairy cows.

\section{MATERIALS AND METHODS}

Animals were cared for and handled in accordance with the Canadian Council on Animal Care regulations, and the University of Guelph Animal Care Committee reviewed and approved the experiment and all procedures carried out in the study.

\section{Animals and Experimental Design}

Ninety multiparous Holstein dairy cows were randomly assigned to 1 of 3 treatments: 1) no nutrients supplemented in the drinking water (control), and 2 isoenergetic treatments: 2) $20 \mathrm{~g} / \mathrm{L}$ of glycerin $(99.7 \%$ glycerol, specific gravity, 1.249; The Kissner Group, Cambridge, Ontario, Canada) supplemented in the drinking water from $7 \mathrm{~d}$ prepartum to $7 \mathrm{~d}$ postpartum (glycerol); and 3) $10 \mathrm{~g} / \mathrm{L}$ of soybean oil supplemented in the drinking water from 7-d prepartum to 7-d postpartum (SBO). The level of inclusion of glycerol and SBO was based on previous work, which supplemented glucose at $20 \mathrm{~g} / \mathrm{L}$ in the drinking water of periparturient cows (Osborne et al., 2002) such that approximately $800 \mathrm{~g} / \mathrm{d}$ of glycerol and $400 \mathrm{~g} / \mathrm{d}$ of SBO were delivered prepartum and 1,600 and $800 \mathrm{~g} / \mathrm{d}$ of glycerol and SBO, respectively, were delivered postpartum (based on a 40and $80-\mathrm{L} / \mathrm{d}$ water consumption pre- and postpartum, respectively). The water supplementation and delivery system has been described elsewhere (Osborne et al., 2008). Cows were housed in individual maternity pens and tie-stalls and offered a close-up and milking cow TMR twice daily at 0800 and $1500 \mathrm{~h}$ for ad libitum intake pre- and postpartum, respectively. The ingredients and chemical composition of the close-up and milking cow TMR are presented in Table 1.
Table 1. Ingredients and chemical composition of close-up and lactating cow TMR

\begin{tabular}{lcc}
\hline & \multicolumn{2}{c}{ TMR } \\
\cline { 2 - 3 } Item & Close-up & Lactating cow \\
\hline Ingredient, \% & \\
Corn silage & 61.0 & 32.5 \\
Alfalfa silage & 10.8 & 21.7 \\
High-moisture corn & 5.8 & 20.5 \\
First-cut mixed hay & 7.1 & 5.3 \\
TMR dairy supplement & $15.3^{1}$ & $20.0^{2}$ \\
Chemical composition & & \\
DM, \% & 37.9 & 43.3 \\
CP, \% of DM (N $\times 6.25)$ & 13.8 & 16.1 \\
ADF, \% of DM & 23.7 & 21.9 \\
NDF, \% of DM & 41.5 & 39.3 \\
Ca, \% of DM & 0.81 & 0.91 \\
P, \% of DM & 0.36 & 0.42 \\
K, \% of DM & 1.26 & 1.29 \\
Mg, \% of DM & 0.29 & 0.29 \\
Na, \% of DM & 0.15 & 0.35 \\
NE ${ }^{3}$ Mcal/kg & 1.51 & 1.54 \\
\hline
\end{tabular}

${ }^{1}$ Contained (g/kg of DM): 48\% soybean meal, 673; canola meal, 90; wheat bran, 80; calcium carbonate (limestone), 49.5; dicalcium phosphate, 14.5; fine salt, 16.1; molasses (in pelleter), 20; urea, 14.0; magnesium oxide $(56 \% \mathrm{Mg}), 6.9$; vitamin E $(50 \mathrm{kIU} / \mathrm{kg}), 14.8$; Organic ruminant Micro Premix (Floradale Feed Mill Ltd., Floradale, Ontario, Canada), 7.5; selenium 200, 6.8; sulfur flour 99.5\%, 1.8; Yea-Sacc ${ }^{1026}$ (Alltech Inc., Nicholasville, KY), 4.8; Rovimix H-2 (DSM Nutritional Products Inc., Parsippany, NJ), 0.3.

${ }^{2}$ Contained $(\mathrm{g} / \mathrm{kg}$ of $\mathrm{DM}): 48 \%$ soybean meal, 237 ; high-protein corn gluten meal, 200; canola meal, 100; roasted soybean (whole), 100; soy hulls (ground), 50.5; fish meal (herring), 50; beet pulp, 50; sodium bicarbonate, 33; calcium carbonate (limestone), 54.6; dicalcium phosphate, 23.6; fine salt, 21.7; golden flake (Floradale Feed Mill Ltd.), 20 ; molasses (in pelleter), 20; urea, 20; magnesium oxide $(56 \% \mathrm{Mg}$ ), 7.2; organic ruminant Micro Premix (Floradale Feed Mill Ltd.), 5.4; Fibrozyme (Alltech Inc.), 2.7; sulfur flour 99.5\%, 2.3; Yea-Sacc ${ }^{1026}$ (Alltech Inc.), 1.9; Rovimix H-2 (DSM Nutritional Products), 0.1.

${ }^{3}$ Estimated according to the NRC (2001).

\section{Measurements}

Water and feed intake were monitored daily. The amount of TMR offered and refused for each cow was measured daily. Samples of TMR and orts were obtained daily and dried at $60^{\circ} \mathrm{C}$ for $48 \mathrm{~h}$ for DM determination. The TMR samples were pooled twice weekly and sent to a commercial laboratory (Agri-Food Laboratories, Guelph, Ontario, Canada) for chemical composition analysis.

All cows were weighed and body condition scored before morning feeding at $7 \mathrm{~d}$ before parturition and at parturition. At $7 \mathrm{~d}$ postpartum, the cows were weighed and body condition scored after the morning milking. Body condition score was assessed by the same individual using a 5 -point scale $(1=$ thin to $5=$ fat $)$ in 0.25-unit increments (Edmonson et al., 1989). Calf weights at birth were recorded before the first colostrum was offered. 
Cows were milked twice daily at 0630 and $1630 \mathrm{~h}$, and milk production was recorded at each milking. Composite morning and evening milk samples were obtained on the first $6 \mathrm{~d}$ of lactation. Blood samples were obtained daily at $0700 \mathrm{~h}$ into evacuated $10-\mathrm{mL}$ test tubes (Vacutainer, Becton Dickinson, Rutherford, NJ) by venipuncture of the coccygeal vessels. Samples were placed on ice and centrifuged at 2,000 $\times g$ for $15 \mathrm{~min}$ in a refrigerated centrifuge (Model TJ-6, Beckman, Palo Alto, CA) at $4^{\circ} \mathrm{C}$ within $30 \mathrm{~min}$. Serum was separated and transferred to $7-\mathrm{mL}$ plastic scintillation vials and stored at $-70^{\circ} \mathrm{C}$ until analysis.

\section{Chemical Analysis}

Analytical DM content of the TMR was determined by oven drying at $135^{\circ} \mathrm{C}$ for $2 \mathrm{~h}$ (method 3.002; AOAC, 1990). The CP contents were determined using Leco FP $428 \mathrm{~N}$ analyzer (Leco Corporation, St. Joseph, MI; method 4.2.08; AOAC, 1990). The TMR samples were also analyzed for ADF (method 973.18c; AOAC, 1990) and NDF (Van Soest et al., 1991) using $\alpha$-amylase (A3306; Sigma Chemical Co., St. Louis, MO), and sodium sulfite corrected for ash concentration adapted for an Ankom 200 fiber analyzer (Ankom Technology, Fairport, NY). Calcium, phosphorus, potassium, magnesium, and sodium were analyzed by inductively coupled plasma spectroscopy (method 945.46; AOAC, 1990).

Milk samples were analyzed for true protein, fat, and lactose using infrared spectroscopy (MilkoScan FT 120, Foss Analytical A/S, Hillerød, Denmark). The concentration of BHBA in serum was determined using the Sigma Diagnostics enzymatic method (kit 310-A, Sigma) following the methods of Williamson et al. (1962). Nonesterified fatty acid concentrations were determined using a colorimetric assay (NEFA-C kit, Wako Chemicals, Richmond, VA), following modifications by Johnson and Peters (1993), and glucose concentrations were determined using a colorimetric assay (kit GAGO20, Sigma) following the methods of Raabo and Terkildsen (1960). Triacylglycerol concentrations were determined using a colorimetric assay (kit TRO100, Sigma) following the methods of McGowan et al. (1983). Glycerol and soybean oil gross energy values were determined using a C5000 bomb calorimeter (IKA Works Inc., Wilmington, NC).

\section{Energy Balance Calculations}

Total net energy intake $\left(\mathbf{T N E}_{\mathbf{I}}\right)$ was determined from DMI and glycerol or SBO intakes in water. The $\mathrm{NE}_{\mathrm{L}}$ content of the TMR was calculated according to NRC (2001) and $\mathrm{NE}_{\mathrm{L}}$ contents of glycerol and SBO were esti- mated at 59 and $64 \%$, respectively, of the gross energy values (NRC, 2001) to be 2.5 and $6.0 \mathrm{Mcal} / \mathrm{kg}$ of DM, respectively. Net energy for maintenance (Mcal/d) was computed as $\mathrm{BW}^{0.75} \times 0.08(\mathrm{NRC}, 2001)$. Pregnancy energy expenditures $\left(\mathbf{N E}_{\mathbf{P}}\right)$ were calculated as $[(2 \times$ $0.00159 \times$ days pregnant -0.0353$) \times$ calf $\mathrm{BW} / 45] / 0.14$ $\times 0.64$ (NRC, 2001). Milk energy was calculated using the equation $\mathrm{NE}_{\mathrm{L}}(\mathrm{Mcal} / \mathrm{d})=\mathrm{MP} \times[(0.0929 \times \mathrm{F})$ $+(0.0563 \times \mathrm{P})+(0.0395 \times \mathrm{L})]$, where MP is milk production $(\mathrm{kg} / \mathrm{d})$, and $\mathrm{F}, \mathrm{P}$, and $\mathrm{L}$ are fat, protein, and lactose percentages in the milk, respectively (NRC, 2001). Energy balance (Mcal/d) was estimated as $\mathrm{TNE}_{\mathrm{I}}$ $-\left(\mathrm{NE}_{\mathrm{M}}+\mathrm{NE}_{\mathrm{P}}+\mathrm{NE}_{\mathrm{L}}\right)$.

\section{Statistical Analysis}

The ANOVA for DMI, BW, DMI as a percentage of BW, BW change, BCS, BCS change, water and energy intake, energy balance, and milk production and composition was conducted separately by period (i.e., $\mathrm{d}-7$ to $\mathrm{d}-1$, at parturition, and $\mathrm{d} 1$ to $\mathrm{d} 7$ ) using PROC MIXED of SAS (v. 9.1; SAS Inst. Inc., Cary, NC). The model was: $Y_{\mathrm{ij}}=\mu+\alpha_{\mathrm{i}}+\beta_{\mathrm{j}}+\alpha \beta_{\mathrm{ij}}+\varepsilon_{\mathrm{ij}}$, where $\mathrm{Y}_{\mathrm{ij}}$ is the dependent variable, $\mu$ is the overall mean, $\alpha_{i}$ is the effect of treatment $\left({ }_{i}=1,2,3\right), \beta_{\mathrm{j}}$ is the effect of time in days $(\mathrm{j}=-7,-6,-5,-4,-3,-2,-1$ or $1,2,3,4$, $5,6,7), \alpha \beta_{\mathrm{ij}}$ is the effect of a treatment $\times$ time interaction $\left({ }_{\mathrm{ij}}=1,2, \ldots, 21\right)$, and $\varepsilon_{\mathrm{ij}}$ is the random residual error. The repeated measurement option in time was used with cow nested within treatment as the repeat subject for variables with repeated measurements. The first-order autoregressive covariance model was fitted to the data. The correlation between energy intake, energy balance and blood metabolites was conducted using PROC CORR in SAS. Differences among treatment means were tested for significance using Tukey's honestly significant difference, and effects were considered significant at $P<0.05$. Data are expressed as least squares means \pm SEM, which represents the pooled SE for the model.

\section{RESULTS AND DISCUSSION}

Of the 90 cows assigned to treatments, only 70 completed the trial (20 on the control treatment, 24 on glycerol, and 26 on soybean oil). The remaining cows calved early and were not included in the statistical analysis.

\section{DMI and Water Intake}

During the prepartum period, cows supplemented with glycerol and SBO had lower $(P=0.03)$ DMI than the control cows (Table 2). However, DMI of glycerol 
Table 2. Effects of supplementing glycerol and soybean oil (SBO) in drinking water of dairy cows from d 7 before calving to $7 \mathrm{~d}$ postpartum on DMI, BW, BCS, water intake, and energy balance

\begin{tabular}{|c|c|c|c|c|c|}
\hline \multirow[b]{2}{*}{ Item } & \multicolumn{3}{|c|}{ Treatment } & \multirow[b]{2}{*}{ SEM } & \multirow[b]{2}{*}{$P$-value } \\
\hline & Control & Glycerol & $\mathrm{SBO}$ & & \\
\hline \multicolumn{6}{|l|}{ Prepartum $^{1}$} \\
\hline DMI, kg/d & $12.4^{\mathrm{a}}$ & $10.9^{\mathrm{b}}$ & $11.3^{\mathrm{b}}$ & 0.42 & 0.03 \\
\hline DMI, $\%$ of BW & 1.82 & 1.57 & 1.62 & 0.134 & 0.37 \\
\hline $\mathrm{BW},{ }^{2} \mathrm{~kg}$ & 731 & 756 & 747 & 14.3 & 0.47 \\
\hline BW change ${ }^{3}$ & $14.9^{\mathrm{a}}$ & $34.0^{\mathrm{b}}$ & $18.5^{\mathrm{a}}$ & 2.58 & $<0.01$ \\
\hline $\mathrm{BCS}^{4}$ & 3.74 & 3.69 & 3.58 & 0.116 & 0.62 \\
\hline BCS change $^{4}$ & 0.14 & 0.15 & 0.21 & 0.047 & 0.51 \\
\hline Water intake, L/d & $34.9^{\mathrm{a}}$ & $33.6^{\mathrm{ab}}$ & $29.4^{\mathrm{b}}$ & 1.64 & 0.05 \\
\hline NE intake, ${ }^{5} \mathrm{Mcal} / \mathrm{d}$ & 18.8 & 18.7 & 18.7 & 0.67 & 0.99 \\
\hline NE balance, ${ }^{5}$ Mcal/d & 3.36 & 3.17 & 3.16 & 0.774 & 0.98 \\
\hline \multicolumn{6}{|l|}{ Postpartum ${ }^{6}$} \\
\hline DMI, kg/d & $15.1^{\mathrm{a}}$ & $12.6^{\mathrm{b}}$ & $13.3^{\mathrm{b}}$ & 0.48 & $<0.01$ \\
\hline DMI, $\%$ of BW & 2.22 & 1.87 & 2.00 & 0.082 & 0.01 \\
\hline $\mathrm{BW}{ }^{7} \mathrm{~kg}$ & 682 & 701 & 689 & 16.8 & 0.74 \\
\hline BW change ${ }^{8}$ & $-27.2^{\mathrm{a}}$ & $-30.3^{\mathrm{ab}}$ & $-33.7^{\mathrm{b}}$ & 1.38 & $<0.01$ \\
\hline $\mathrm{BCS}^{9}$ & 3.57 & 3.53 & 3.45 & 0.106 & 0.72 \\
\hline BCS change $^{9}$ & -0.16 & -0.18 & -0.16 & 0.017 & 0.85 \\
\hline Water intake, L/d & $68.7^{\mathrm{a}}$ & $66.8^{\mathrm{a}}$ & $58.3^{\mathrm{b}}$ & 2.66 & 0.02 \\
\hline NE intake ${ }^{5}$ Mcal/d & 23.3 & 24.0 & 23.8 & 0.79 & 0.83 \\
\hline NE balance, ${ }^{5} \mathrm{Mcal} / \mathrm{d}$ & -14.6 & -14.2 & -14.4 & 1.28 & 0.98 \\
\hline \multicolumn{6}{|c|}{ a,b Means within a row with different superscript letters differ $(P<0.05)$} \\
\hline \multicolumn{6}{|c|}{${ }^{1}$ Last $7 \mathrm{~d}$ of gestation. } \\
\hline \multicolumn{6}{|c|}{${ }^{2}$ Mean BW from $7 \mathrm{~d}$ precalving to calving. } \\
\hline \multicolumn{6}{|c|}{${ }^{3}$ Difference between precalving and calving data. } \\
\hline \multicolumn{6}{|c|}{${ }^{4} \mathrm{BCS}: 1=$ thin, $5=$ fat; mean BCS at $7 \mathrm{~d}$ precalving. } \\
\hline \multicolumn{6}{|c|}{${ }^{5}$ Calculated according to the NRC (2001). } \\
\hline \multicolumn{6}{|c|}{${ }^{6}$ First $7 \mathrm{~d}$ of the lactation period. } \\
\hline \multicolumn{6}{|c|}{${ }^{7}$ Mean BW from calving to $7 \mathrm{~d}$ postcalving. } \\
\hline${ }^{8}$ Difference between cal & and data & ostcal & & & \\
\hline
\end{tabular}

and SBO cows were not $(P>0.05)$ different. DeFrain et al. (2004) evaluated the antiketogenic effects of glycerol top-dressed on the TMR of dairy cows during the transition period and observed that prepartum, DMI was greater for control cows compared with those fed glycerol in agreement with the results of the current study (Table 2).

During the postpartum period, cows supplemented with glycerol and SBO had lower $(P<0.01)$ DMI than the control cows. However, DMI of glycerol and SBO cows were not $(P>0.05)$ different (Table 2). Previous studies have shown that feeding unsaturated oil depressed DMI (Lock and Shingfield, 2004) because of impaired rumen function (Jenkins, 1993). Fisher et al. (1971) found that glycerol acted as an appetite stimulant when fed at $472 \mathrm{~g} / \mathrm{d}$ within the concentrate mix of a component-based diet compared with cows fed propylene glycol, whereas Fisher et al. (1973) found that feeding glycerol at 174 or $347 \mathrm{~g} / \mathrm{d}$ did not improve feed intake, milk yield, and energy balance compared with unsupplemented cows or cows supplemented with propylene glycol. Chung et al. (2007) fed a dry glycerol product (food grade, $65 \%$ glycerol) to supply $163 \mathrm{~g}$ of glycerol per day to 39 multiparous Holstein dairy cows from calving to $21 \mathrm{DIM}$ and found no effect on feed intake. However, in a recent study, Donkin and Doane (2007) evaluated the dose response of feeding 0, 50, 100 , and $150 \mathrm{~g} / \mathrm{kg}$ of glycerol $(99.5 \%$ pure glycerol) of diet DM $(1,222,2,454$, and 3,600 g/d of glycerol for 50 , 100 , and $150 \mathrm{~g} / \mathrm{kg}$ of glycerol, respectively) to lactating dairy cows and found that feed intake was decreased at the $150 \mathrm{~g} / \mathrm{kg}$ level of glycerol during the first $7 \mathrm{~d}$ of the experiment. In the current study, supplementing glycerol and SBO in the drinking water lowered DMI during the first $7 \mathrm{~d}$ of the experiment. The effects of glycerol both pre- and postpartum in the current study are consistent with previous studies although our study is different from those that have added glycerol or SBO to the TMR because we provided these energy sources via drinking water instead of top-dressing on the basal diet. Because animals eat primarily to meet their energy requirements (Church and Pond, 1988), if an animal is in positive energy balance providing additional metabolizable energy would theoretically decrease feed intake and thus improve efficiency. Ogborn (2006) drenched multiparous Holstein cows with $500 \mathrm{~mL} / \mathrm{d}$ of glycerol 


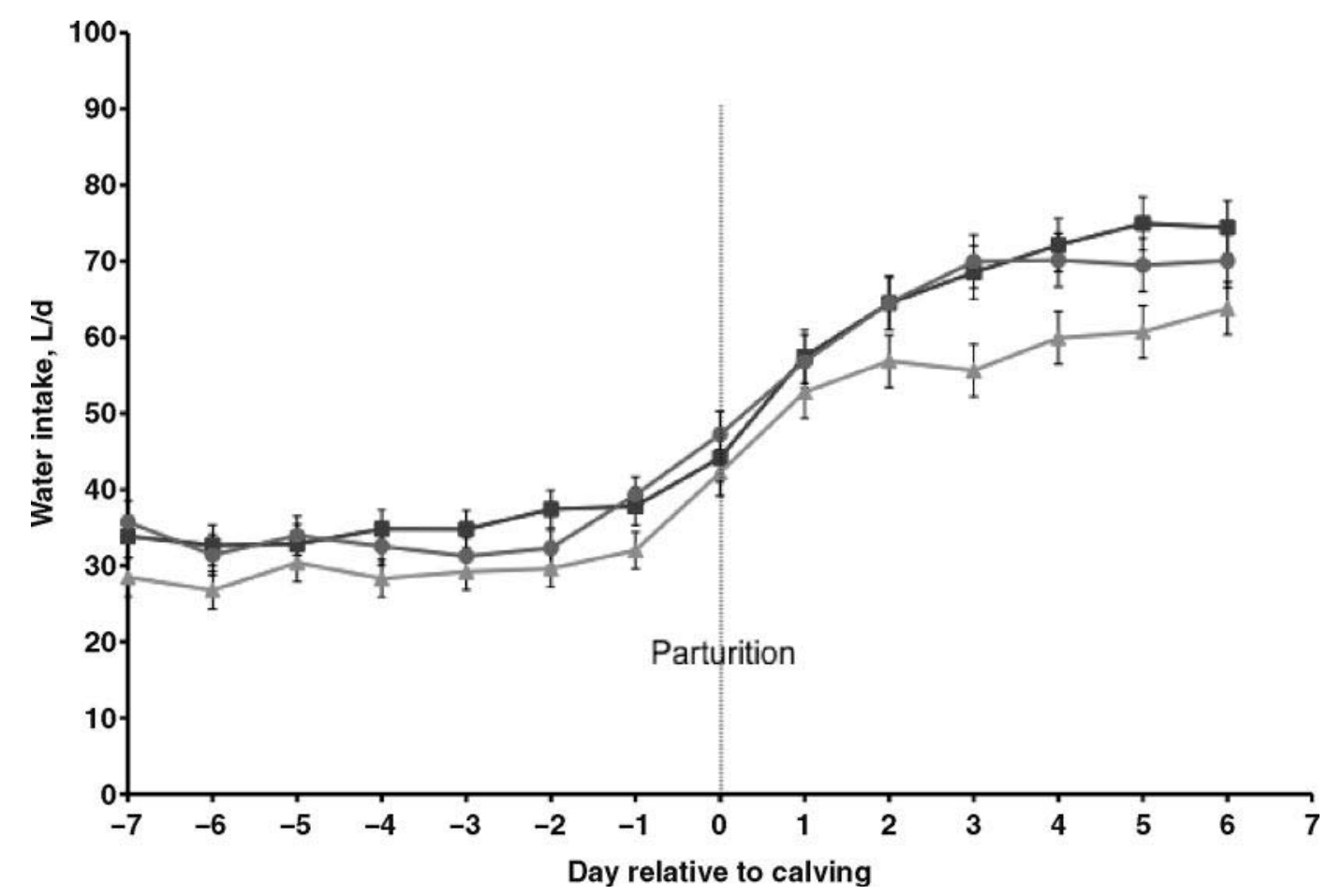

Figure 1. Water intake for the control cows before calving to $7 \mathrm{~d}$ postpartum.

for the first 5 DIM and observed decreased DMI. Feeding glycerol during the prepartum period in the Ogborn (2006) study increased DMI, but feeding glycerol during the postpartum period tended to decrease DMI.

During the prepartum period, there were no differences $(P>0.05)$ in the water intake of glycerol cows and either the control cows or those supplemented with SBO. However, during the postpartum period, water intake of the control cows was greater $(P=0.02)$ than that of cows supplemented with SBO but similar to that of cows supplemented with glycerol. This is in contrast to Schröder and Südekum (1999) who found that feeding glycerol in the diet stimulated water intake. Water intake of the lactating cows supplemented with glycerol in the current study was greater $(P=0.02)$ than that of cows supplemented with SBO (Table 2, Figure 1).

\section{Energy Balance, BW, and BCS}

All cows were in positive energy balance before calving and in negative energy balance after calving (Figure $2)$. There were no differences $(P>0.05)$ in energy intake and energy balance of the cows throughout the experimental period (Table 2, Figure 2). During the prepartum period, cows supplemented with glycerol showed an almost 2-fold increase in BW gain compared with the control or cows supplemented with SBO. However, no conclusion(s) can be drawn from weight changes in such a short experimental period. Furthermore, there are great limitations to measuring BCS change over such a short duration to avoid ending up with artifacts. There were no differences in the change in BW between cows supplemented with SBO and the control cows. There were no differences $(P>0.05)$ in BW, BCS, or BCS changes.

During the postpartum period, there were no differences $(P>0.05)$ in the BCS change of cows supplemented with glycerol compared with control cows or cows supplemented with SBO. In the Donkin and Doane (2007) study, cows supplemented with $150 \mathrm{~g} / \mathrm{kg}$ glycerol gained more weight after $8 \mathrm{wk}$ on the diet than did cows fed other treatments. However, in the current study, the experiment was only from d 7 prepartum to d 7 postpartum, and the observed changes in BCS and BW were typical of BCS and BW changes in the herd. This lack of effect was not surprising because BCS is primarily an assessment of subcutaneous tissue change and measuring BCS over a relatively short period of time gives no clear indication of whether a cow was gaining or losing weight. Furthermore, when a cow begins to replenish mobilized tissue, abdominal and intermuscular fat, which contribute significantly to the total energy available for mobilization (Butler-Hogg et al., 1985), are replenished before subcutaneous fat. 


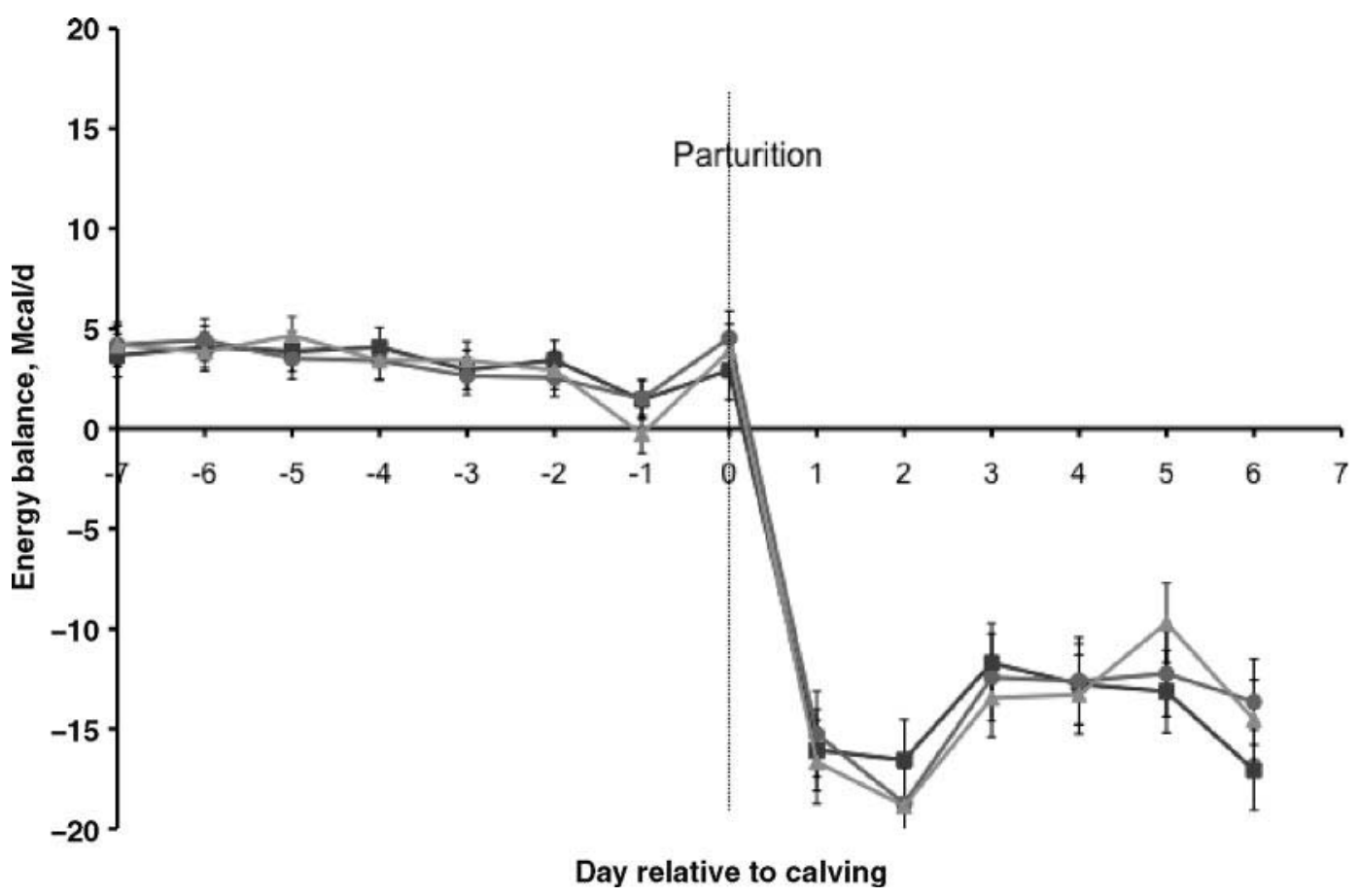

Figure 2. Energy balance for the control cows $(\mathbf{\square})$ and cows supplemented with glycerol before calving to $7 \mathrm{~d}$ postpartum.

\section{Triacylglycerol}

Soybean oil was supplemented in the drinking water as a source of triacylglycerol for ATP production and milk fat synthesis. The concentration of triacylglycerol in the serum of SBO-supplemented cows was greater $(P<0.01)$ than in glycerol cows during the prepartum period, was greater $(P=0.03)$ than in control cows at parturition, and was greater $(P<0.01)$ than in control and glycerol cows postpartum (Figure 3A). The concentrations of triacylglycerol averaged 189.0, 174.6, and $205.3 \pm 7.25 \mu \mathrm{mol} / \mathrm{L}$ for the control, glycerol and SBO treatments, respectively, during the prepartum period; $112.7,122.8$, and $139.0 \pm 8.85 \mu \mathrm{mol} / \mathrm{L}$, respectively, at parturition; and 99.5, 97.4, and $120.0 \pm 3.43 \mu \mathrm{mol} / \mathrm{L}$, respectively, postpartum. Glycerol caused a decrease in serum triacylglycerol concentrations prepartum, which may have been a consequence of depressed DMI, although the effect did not persist into lactation.

\section{NEFA}

The concentration of NEFA in serum of all cows remained relatively constant from $\mathrm{d}-7$ to -3 and then began to increase at $2 \mathrm{~d}$ before parturition (Figure 3B). Grummer (1993) suggested that this rapid increase in the concentration of serum NEFA immediately before calving may be hormonally regulated. It has been sug- gested that the spike at calving is associated with the sharp reduction in intake and with the elevation in plasma lipolytic hormones that occurs in conjunction with the onset of calving (Vázquez-Añón et al., 1994). There were no differences $(P=0.20)$ in the concentration of NEFA in serum during the prepartum period, which averaged $0.21,0.30$, and $0.26 \pm 0.037 \mathrm{mmol} / \mathrm{L}$ for the control, glycerol, and SBO treatments, respectively. The concentration of serum NEFA prepartum was negatively correlated to the concentration of triacylglycerol $(\mathrm{r}=-0.62 ; P<0.01)$. Similar to the prepartum period, there were no differences $(P=0.53)$ in the concentration of NEFA in serum at parturition, which averaged $0.57,0.62$, and $0.52 \pm 0.066 \mathrm{mmol} / \mathrm{L}$ for the control, glycerol, and SBO treatments, respectively. These results are in agreement with those of Ogborn (2006), who orally drenched transition cows with crude glycerol (625 g of glycerol/d) during the first $5 \mathrm{~d}$ postpartum and observed a reduction in DMI but no changes in plasma glucose and NEFA concentrations. There were also no differences $(P=0.22)$ in the serum concentrations of NEFA postpartum, which averaged 0.63, 0.50, and $0.58 \pm 0.050 \mathrm{mmol} / \mathrm{L}$ for the control, glycerol, and SBO treatments, respectively, in contrast to DeFrain et al. (2004), who observed decreased concentrations of NEFA in serum of glycerol-supplemented cows.

Elevated concentration of serum NEFA during the periparturient period is a common feature in dairy cows 

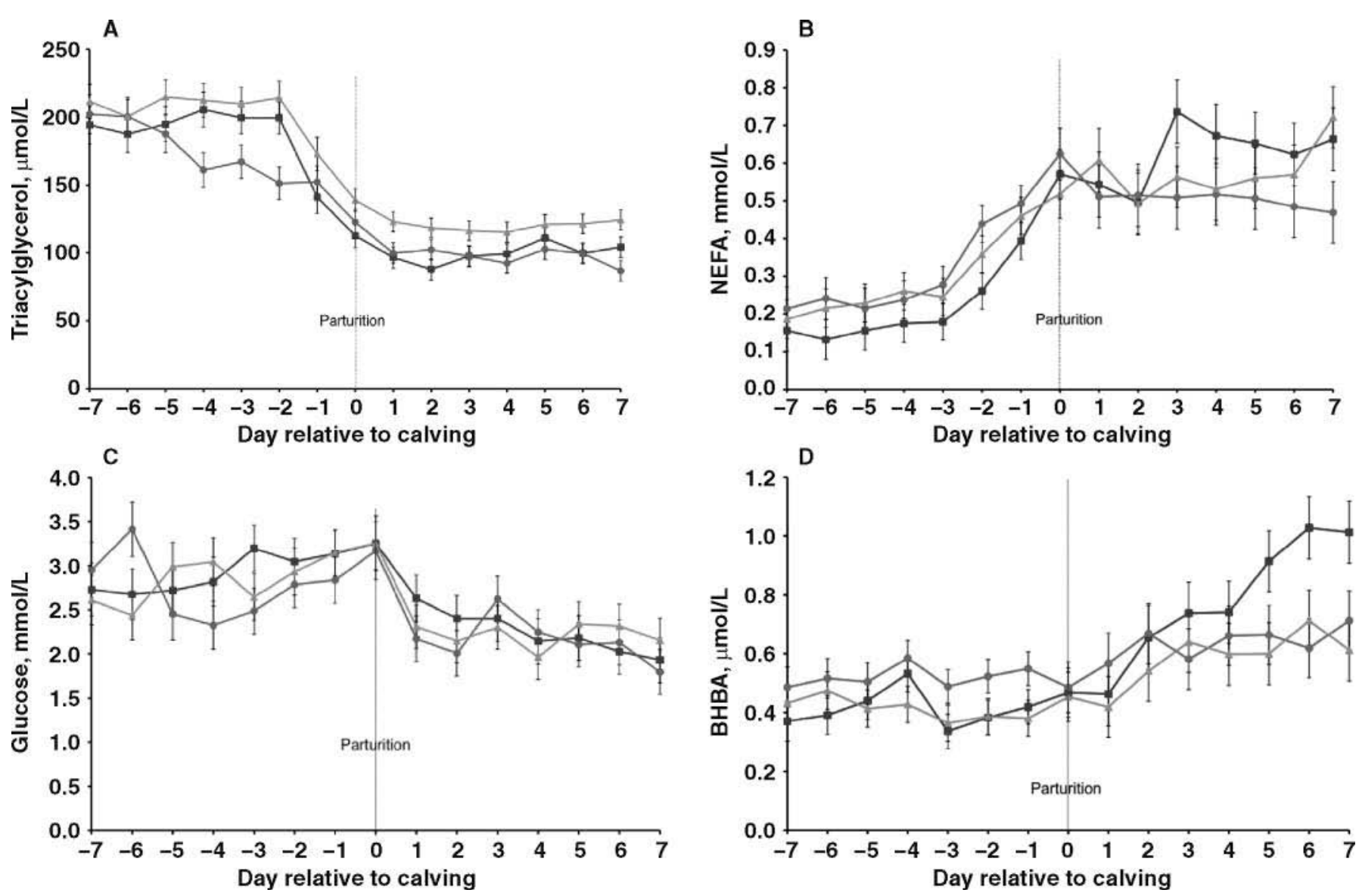

Figure 3. Serum metabolite concentrations of dairy cows on the control treatment (no supplementation; $\mathbf{\square}$ ) and those supplemented with glycerol $(\bullet)$ and soybean oil $(\mathbf{\Lambda})$ in drinking water from d 7 before calving to $7 \mathrm{~d}$ postpartum: a) triacylglycerol; b) NEFA; c) glucose; and d) BHBA.

and reflects increased reliance on adipose reserves to support energy requirements and milk fat synthesis (Pullen et al., 1989). The magnitude of the increase in NEFA after parturition was inversely related to DMI before parturition (Holtenius et al., 2003). High serum NEFA concentration leads to triacylglycerol accumulation in muscle (Roberts et al., 1981) and liver (Roberts et al., 1981; Grummer, 1993) and has been associated with depressed DMI and metabolic disorders (Grummer, 1993).

\section{Glucose}

There were no differences in the concentrations of glucose in serum prepartum $(P=0.82)$, at parturition $(P=0.98)$, and postpartum $(P=0.92$; Figure $3 \mathrm{C})$. The concentration of glucose in serum averaged 2.90, 2.75, and $2.83 \pm 0.165 \mathrm{mmol} / \mathrm{L}$ for the control, glycerol, and SBO treatments, respectively, during the prepartum period; $3.25,3.17$, and $3.25 \pm 0.313 \mathrm{mmol} / \mathrm{L}$, respectively, at parturition; and $2.24,2.15$, and $2.22 \pm 0.161 \mathrm{mmol} / \mathrm{L}$, respectively, postpartum. Although Rukkwamsuk et al. (1999) reported that high-energy diets increased the concentration of plasma glucose during the last week of gestation, our results are in agreement with those of DeFrain et al. (2004) who top-dressed either 430 or 860 $\mathrm{g} / \mathrm{d}$ of glycerol onto the daily TMR allocation of dairy cows during the transition period from $\mathrm{d}-14$ to $\mathrm{d} 21$ postpartum and found that prepartum plasma glucose and insulin concentrations were not affected by treatments. Postpartum, supplementing $430 \mathrm{~g} / \mathrm{d}$ of glycerol lowered blood glucose concentrations at $\mathrm{d} 7$ and BHBA concentrations at d 14 and d 21, whereas supplementing $860 \mathrm{~g} / \mathrm{d}$ of glycerol led to a decrease in glucose concentration from d 14 to 21 and elevated BHBA concentrations from d 7 (DeFrain et al., 2004). DeFrain et al. (2004) suggested that dietary glycerol during the transition period may only provide modest support to increase postpartum serum glucose concentrations and decrease NEFA. The decreased glucose concentrations in all treatments postpartum were probably related to the low DMI and the concomitant reduction in propi- 
onate absorption, along with an increased glucose use in milk synthesis (Doepel et al., 2002).

\section{BHBA}

The concentration of BHBA in the serum of the glycerol cows was greater $(P=0.05)$ than for control and SBO cows during the prepartum period, whereas during the postpartum period the concentration of BHBA of the control cows was greater $(P=0.02)$. There were no differences in the concentration of BHBA at parturition (Figure 3D). The concentration of BHBA in serum of the control cows was greater $(P<0.01)$ than that for glycerol and SBO cows postpartum. There was no difference $(P>0.05)$ in concentration of BHBA in serum of glycerol and SBO cows. The concentration of BHBA in serum averaged $0.41,0.52$, and $0.41 \pm 0.036$ $\mu \mathrm{mol} / \mathrm{L}$ for the control, glycerol, and SBO treatments, respectively, during the prepartum period; 0.47, 0.49, and $0.45 \pm 0.084 \mu \mathrm{mol} / \mathrm{L}$, respectively, at parturition; and $0.79,0.64$, and $0.59 \pm 0.053 \mu \mathrm{mol} / \mathrm{L}$, respectively, postpartum. Chung et al. (2007) showed that glycerinsupplemented cows exhibited a more-positive energy status during the second week of lactation as evidenced by greater concentrations of plasma glucose, lower concentrations of plasma BHBA, and lower concentrations of urine ketones. In the current study, there were no differences in the concentration of glucose during the first 7 DIM.

There was a tendency for the concentration of serum BHBA during the prepartum period to be negatively correlated to the concentration of triacylglycerol $(\mathrm{r}=$ $-0.41 ; P=0.06)$. The concentration of serum BHBA postpartum was negatively correlated to the concentration of glucose $(\mathrm{r}=-0.46 ; P=0.04)$ and tended to be positively correlated to the concentration of NEFA ( $\mathrm{r}$ $=0.42 ; P=0.06$ ). The increased serum concentrations of NEFA and BHBA postpartum suggest mobilization of body fat as indicated by the reductions in BW and BCS. Although water supplementation had no effect on NE balance or serum glucose and NEFA concentrations, BHBA concentrations in serum were decreased. The decrease may have been unrelated to fat mobilization and due to the reduced DMI on glycerol and SBO treatments, leading to lower production and absorption of butyrate from rumen fermentation.

\section{Milk Yield and Composition}

There were no effects $(P>0.05)$ of glycerol or SBO on calf birth weight or milk yield and composition (Table 3). Khalili et al. (1997) fed $36 \mathrm{~g}$ of glycerol/kg of diet DM to mid-lactation dairy cows and reported no effects on feed intake, milk production, and composi- tion, although the profile of fatty acids in milk was slightly altered. Donkin and Doane (2007) found that milk production and composition were not affected by glycerol addition up to $150 \mathrm{~g} / \mathrm{kg}$ of dietary DM. Similarly, Chung et al. (2007) fed $163 \mathrm{~g}$ of glycerol per day from calving to 21 DIM and reported no difference in milk yield and components. Earlier glycerol feeding studies (Fisher et al., 1971, 1973) also found no effect of glycerol on milk yield. However, Bodarski et al. (2005) observed that feeding $500 \mathrm{~mL}$ of glycerol or approximately $31 \mathrm{~g} / \mathrm{kg}$ of ration DM from 3 wk prepartum through 70 DIM increased milk yield and milk protein content during the second week of lactation but there was no treatment effect over the course of the study.

Milk yield was not affected by feeding or drenching glycerol during the first $5 \mathrm{~d}$ of lactation although increasing dietary energy density prepartum has been shown to have a positive effect on milk yield and milk constituents in some studies (Keady et al., 2001; McNamara et al., 2003). There are no studies that have looked at the addition of SBO in the drinking water of dairy cows on milk yield and composition, although addition of SBO to the TMR $(0,17$, and $34 \mathrm{~g} / \mathrm{kg}$ of DM) has been shown to linearly reduce milk fat yield and protein percentage and linearly increase milk yield and milk protein yield (AlZahal et al., 2008). Although milk yield was not affected by addition of SBO in the current study, DMI was depressed. Osborne et al. (2008), in an attempt to bypass the rumen with fish oil and increase n-3 polyunsaturated fatty acids in milk, found that supplementing fish oil in the drinking water of dairy cows had no effect on DMI, water intake, or milk yield compared with top-dressing the fish oil on the TMR.

In conclusion, although the supplementation of energy sources in drinking water was not sufficient to elicit a milk yield response or change the net energy balance of cows during the first week postpartum, it did lower the concentrations of BHBA in serum postpartum. Glycerol and SBO supplementation lowered DMI but had no effect on NE intake. Soybean oil lowered water intake. However, neither treatment had any effect on calf weight at birth, milk production and composition, and serum NEFA and glucose concentration. These results suggest that glycerol supplemented in the drinking water at $20 \mathrm{~g} / \mathrm{L}$ might not be a viable glucogenic feed additive for transition dairy cows from $7 \mathrm{~d}$ prepartum to $7 \mathrm{~d}$ postpartum.

\section{ACKNOWLEDGMENTS}

The authors thank the Dairy Farmers of Ontario and Ontario Ministry of Agriculture and Food for financial support, the staff at the Elora Dairy Research Centre, 
Table 3. Effects of supplementing glycerol and soybean oil (SBO) in drinking water of dairy cows from d 7 before calving to $7 \mathrm{~d}$ postpartum on calf weight, milk yield and composition

\begin{tabular}{lccccc}
\hline & \multicolumn{3}{c}{ Treatment } & & \\
\cline { 2 - 4 } Item & Control & Glycerol & SBO & SEM & $P$-value \\
\hline Calf weight, $\mathrm{kg}$ & 47.2 & 46.3 & 47.8 & 1.06 & 0.62 \\
Milk yield, ${ }^{\mathrm{kg}} \mathrm{kg} / \mathrm{d}$ & 27.9 & 26.6 & 26.5 & 0.96 & 0.52 \\
Fat, \% & 5.51 & 5.93 & 5.44 & 0.217 & 0.24 \\
Fat yield, $\mathrm{kg} / \mathrm{d}$ & 1.55 & 1.52 & 1.44 & 0.088 & 0.67 \\
Protein, \% & 6.08 & 6.67 & 6.87 & 0.439 & 0.42 \\
Protein yield, kg/d & 1.56 & 1.62 & 1.73 & 0.113 & 0.55 \\
Lactose, $\%$ & 3.69 & 3.58 & 3.60 & 0.068 & 0.51 \\
Lactose yield, $\mathrm{kg} / \mathrm{d}$ & 1.04 & 0.96 & 0.97 & 0.040 & 0.30 \\
SNF, \% & 10.5 & 11.0 & 11.2 & 0.38 & 0.42 \\
SNF yield, $\mathrm{kg} / \mathrm{d}$ & 2.79 & 2.76 & 2.89 & 0.132 & 0.77 \\
\hline
\end{tabular}

${ }^{1}$ First $7 \mathrm{~d}$ of the lactation period.

and Mollie Campbell, Carolyn Borsy, Carmen Chui, and Norm Purdie (Department of Animal and Poultry Science, University of Guelph) for their technical assistance.

\section{REFERENCES}

AlZahal, O., N. E. Odongo, T. Mutsvangwa, M. M. Or-Rashid, T. F. Duffield, R. Bagg, P. Dick, G. Vessie, and B. W. McBride. 2008. Effects of monensin and dietary soybean oil on milk fat percentage and milk fatty acid profile in lactating dairy cows. J. Dairy Sci. 91:1166-1174.

AOAC. 1990. Official Methods of Analysis. Vol. I. 15th ed. AOAC, Arlington, VA.

Bodarski, R., T. Wertelecki, F. Bommer, and S. Gosiewski. 2005. The changes of metabolic status and lactation performance in dairy cows under feeding TMR with glycerin (glycerol) supplement at periparturient period. Electronic Journal of Polish Agricultural Universities, Animal Husbandry, 8:1-9. Available online: http:// www.ejpau.media.pl/volume8/issue4/art-22.html

Burhans, W. S., A. W. Bell, R. Nadeau, and J. R. Knapp. 2003. Factors associated with transition cow ketosis incidence in selected New England herds. J. Dairy Sci. 86(Suppl. 1):247. (Abstr.)

Butler-Hogg, B. W., J. D. Wood, and J. A. Bines. 1985. Fat partitioning in British Friesian cows: The influence of physiological state on dissected body composition. J. Agric. Sci. (Camb.) 104:519-528.

Chung, Y. H., D. E. Rico, C. M. Martinez, T. W. Cassidy, N. Noirot, A. Ames, and G. A. Varga. 2007. Effects of feeding dry glycerin to early postpartum holstein dairy cows on lactational performance and metabolic profiles. J. Dairy Sci. 90:5682-5691.

Church, D. C., and W. G. Pond. 1988 Basic Animal Nutrition and Feeding. 3rd ed. John Wiley \& Sons Inc., New York, NY.

Curtis, C. R., H. N. Erb, C. H. Sniffen, R. D. Smith, and D. S. Kronfeld. 1985. Path analysis of dry period nutrition, postpartum metabolic and reproductive disorders, and mastitis in Holstein cows. J. Dairy Sci. 68:2347-2360.

DeFrain, J. M., A. R. Hippen, K. F. Kalscheur, and P. W. Jardon. 2004. Feeding glycerol to transition dairy cows: Effects on blood metabolites and lactation performance. J. Dairy Sci. 87:41954206.

Doepel, L., H. Lapierre, and J. J. Kennelly. 2002. Peripartum performance and metabolism of dairy cows in response to prepartum energy and protein intake. J. Dairy Sci. 85:2315-2334.

Donkin, S., and P. Doane. 2007. Glycerol as a feed ingredient for dairy cows. Tristate Nutrition Dairy Nutrition Conference, April 24 and 25. Available: http://tristatedairy.osu.edu/Proceedings\%202007/ Donkin\%20paper.pdf

Drackley, J. K., T. R. Overton, and G. N. Douglas. 2001. Adaptations of glucose and long-chain fatty acid metabolism in liver of dairy cows during the periparturient period. J. Dairy Sci. 84(E Suppl.):E100-E112.

Edmonson, A. J., I. J. Lean, L. D. Weaver, T. Farver, and G. Webster. 1989. A body condition scoring chart for Holstein dairy cows. J. Dairy Sci. 72:68-78.

Fisher, L. J., J. D. Erfle, G. A. Lodge, and F. D. Sauer. 1973. Effects of propylene glycol or glycerol supplementation of the diet of dairy cows on feed intake, milk yield and composition, and incidence of ketosis. Can. J. Anim. Sci. 53:289-296.

Fisher, L. J., J. D. Erfle, and F. D. Sauer. 1971. Preliminary evaluation of the addition of glucogenic materials to the rations of lactating cows. Can. J. Anim. Sci. 51:721-727.

Grummer, R. R. 1993. Etiology of lipid-related metabolic disorders in periparturient dairy cows. J. Dairy Sci. 76:3882-3896.

Grummer, R. R. 1995. Impact of changes in organic nutrient metabolism on feeding the transition dairy cow. J. Anim. Sci. 73:2820-2833.

Holtenius, K., S. Agenas, C. Delavaud, and Y. Chilliard. 2003. Effects of feeding intensity during the dry period. 2. Metabolic and hormonal responses. J. Dairy Sci. 86:883-891.

Houpt, T. R. 1984. Water balance and excretion. In Duke's Physiology of Domestic Animals. 10th ed. M. J. Swenson, ed. Comstock Publishing Co., New York, NY.

Jenkins, T. C. 1993. Lipid metabolism in the rumen. J. Dairy Sci. 76:3851-3863.

Johnson, M. M., and J. P. Peters. 1993. Technical note: An improved method to quantify nonesterified fatty acids in bovine plasma. J. Anim. Sci. 71:753-756.

Keady, T. W., C. S. Mayne, D. A. Fitzpatrick, and M. A. McCoy. 2001. Effect of concentrate feed level in late gestation on subsequent milk yield, milk composition, and fertility of dairy cows. J. Dairy Sci. 84:1468-1479.

Khalili, H., T. Varvikko, V. Toivonen, K. Hissa, and M. Suvitie. 1997. The effects of added glycerol or unprotected free fatty acids or a combination of the two on silage intake, milk production, rumen fermentation and diet digestibility in cows given grass silage based diets. Agric. Food Sci. Finl. 6:349-362.

Lock, A. L., and K. J. Shingfield. 2004. Optimizing milk composition. Pages 107-188 in Dairying - Using Science to Meet Consumers' Needs. Br. Soc. Anim. Sci. Publ. 29. E. Kebreab, J. Mills, and D. E. Beever, ed. Nottingham University Press, Loughborough, UK.

McGowan, M. W., J. D. Artiss, D. R. Strandbergh, and B. Zak. 1983. A peroxidase-coupled method for the colorimetric determination of serum triglycerides. Clin. Chem. 29:538-542.

McNamara, S., F. P. O'Mara, M. Rath, and J. J. Murphy. 2003. Effects of different transition diets on dry matter intake, milk production, and milk composition in dairy cows. J. Dairy Sci. 86:2397-2408.

Murphy, M. R. 1992. Water metabolism of dairy cattle. J. Dairy Sci $75: 326-333$

NRC. 2001. Nutrient Requirements of Dairy Cattle. 7th rev. ed. National Academy Press, Washington, DC. 
Ogborn, K. L. 2006. Effects of method of delivery of glycerol on performance and metabolism of dairy cows during the transition period. MS thesis. Cornell University, Ithaca, NY.

Osborne, V. R., K. E. Leslie, and B. W. McBride. 2002. Effect of supplementing glucose in drinking water on the energy and nitrogen status of the transition dairy cow. Can. J. Anim. Sci. 82:427-433.

Osborne, V. R., S. Radhakrishnan, N. E. Odongo, A. R. Hill, and B. W. McBride. 2008. Effects of supplementing fish oil in the drinking water of dairy cows on production performance and milk fatty acid composition. J. Anim. Sci. 86:720-729.

Overton, T. R., and M. R. Waldron. 2004. Nutritional management of transition dairy cows: Strategies to optimize metabolic health. J. Dairy Sci. 87(E Suppl.):E105-E119.

Pullen, D. L., D. L. Palmquist, and R. S. Emery. 1989. Effect of days of lactation and methionine hydroxy analog on incorporation of plasma fatty acids into plasma triglycerides. J. Dairy Sci. 72:4958.

Raabo, E., and T. C. Terkildsen. 1960. On the enzymatic determination of blood glucose. Scand. J. Clin. Lab. Invest. 12:402-407.

Roberts, C. J., I. M. Reid, G. J. Rowlands, and A. Patterson. 1981. A fat mobilisation syndrome in dairy cows in early lactation. Vet. Rec. 108:7-9.
Rukkwamsuk, T., T. Wensing, and M. J. H. Geelen. 1999. Effect of overfeeding during the dry period on the rate of esterification in adipose tissue of dairy cows during the periparturient period. J. Dairy Sci. 82:1164-1169.

Schröder, A., and K. H. Südekum. 1999. Glycerol as a by-product of biodiesel production in diets for ruminants. Paper No. 241 in New Horizons for an Old Crop. Proc. 10th Int. Rapeseed Congr., Canberra, Australia; CD_ROM.

Thomas, L. C., T. C. Wright, A. Formusiak, J. P. Cant, and V. R. Osborne. 2007. Use of flavored drinking water in calves and lactating dairy cattle. J. Dairy Sci. 90:3831-3837.

Van Soest, P. J., J. B. Robertson, and B. A. Lewis. 1991. Methods for dietary fiber, neutral detergent fiber, and non-starch polysaccharides in relation to animal nutrition. J. Dairy Sci. 74:3583-3597.

Vázquez-Añón, M., S. Bertics, M. Luck, and R. R. Grummer. 1994. Peripartum liver triglyceride and plasma metabolites in dairy cows. J. Dairy Sci. 77:1521-1528.

Williamson, D. H., J. Mellanby, and H. A. Krebs. 1962. Enzymic determination of $\mathrm{D}(-)-\beta$-hydroxybutyric acid and acetoacetic acid in blood. Biochem. J. 82:90-96. 